Vol. 8 (4): 809-812 (2018)

\title{
INVESTIGATION OF AN IMPORTED MEASLES OUTBREAK
}

\author{
Alma Robo ${ }^{1}$, Elona Kureta ${ }^{1}$, Alma Pura ${ }^{2}$, Iria Preza ${ }^{1}$, Erida Nelaj ${ }^{1}$, \\ Artan Simaku ${ }^{1}$, Eugena Tomini ${ }^{1}$, Silvia Bino ${ }^{1}$ \\ ${ }^{1 *}$ Institute of Public Health, Tirana, Albania; \\ ${ }^{2}$ Directorate of Public Health, Pogradec, Albania;
}

*Corresponding author author Alma Robo, e-mail: almarobo@gmail.com;

Received August, 2018; Accepted September, 2018; Published October, 2018;

DOI: https://doi.org/10.31407/ijees8423

UOI license: http://u-o-i.org/1.01/ijees/50440973

\begin{abstract}
Measles virus infection remains a significant cause of childhood mortality and morbidity despite continued global efforts and the availability of a safe and effective vaccine.. After a 9 year period without confirmed measles cases an imported outbreak occurred in Pogradec district in 2017. Epidemiological investigation was carried out to identify sources of infection, transmission routes, and implement measures of control and prevention. Epidemiological service of Directorate of Public health of Pogradec district (DPH) reported 11 suspected cases out of whom 9 (82.\%) were laboratory-confirmed. The outbreak was imported from Macedonia. The outbreak management team took several measures in response to the outbreak. Immediately a districtwide emergency MCV vaccination campaign was initiated. The campaign included screening and vaccination activities in the city and suburban areas, as well as in a school and recreational center for roma children. Also contact in some remote villages were traced and also vaccinated. The target ages included children 12 months to 14 years of age.
\end{abstract}

Key words: measles, outbreak, surveillance, system, laboratory, immunization 